\begin{tabular}{|lll|}
\hline Diterima & $:$ & 23 Maret 2020 \\
Direvisi & $:$ & 15 Mei 2020 \\
Disetujui & $:$ & 26 Juni 2020 \\
Diterbitkan & $:$ & 27 Juni 2020 \\
\hline
\end{tabular}

\title{
PENERAPAN BERMAIN KONSTRUKSI MAGIC SAND UNTUK MENGEMBANGKAN KEMAMPUAN MOTORIK HALUS ANAK USIA DINI
}

\author{
Fitri Wulandari ${ }^{1}$, Heri Yusuf Muslihin ${ }^{2}$, Lutfi Nur ${ }^{3}$ \\ email: fitriwulandari301@gmail.com ${ }^{1}$, heriyusuf@upi.edu², \\ lutfinur@upi.edu ${ }^{3}$ \\ Program Studi Pendidikan Guru PAUD Universitas Pendidikan Indonesia ${ }^{1,2}$ \\ Program Studi Pendidikan Guru SD Universitas Pendidikan Indonesia ${ }^{3}$ \\ Jalan Dadaha 18, Kahuripan, Kec.Tawang, Tasikmalaya, Indonesia
}

\begin{abstract}
Abstrak: Penelitian ini dilatarbelakangi oleh adanya kemampuan motorik halus anak usia dini yang belum berkembang secara optimal, khususnya dalam keterampilan otot-otot halus dan koordinasi mata dengan tangan. Penelitian ini bertujuan untuk meningkatkan kemampuan motorik halus pada anak usia dini melalui kegiatan bermain konstruksi magic sand. Kegiatan penelitian dilakukan secara kolaboratif dengan guru kelas dengan menerapkan metode Penelitian Tindakan Kelas (PTK). Penelitian ini dilaksanakan sebanyak tiga siklus dengan menggunakan model Kemmis dan Mc. Taggart. Subjek penelitian berjumlah 16 anak, terdiri dari delapan anak laki-laki dan delapan anak perempuan serta satu orang guru mitra. Objek penelitian adalah kemampuan motorik halus anak usia dini melalui kegiatan bermain konstruksi magic sand. Teknik observasi dan dokumentasi digunakan dalam pengumpulan data dan selanjutnya dianalisis dengan menggunakan deskriptif kuantitatif. Instrumen yang digunakan berupa observasi terstruktur dengan capaian indikator setiap kegiatannya. Hasil penelitian menunjukkan adanya peningkatan kemampuan motorik halus melalui kegiatan bermain konstruksi magic sand. Terjadi peningkatan dari setiap siklus penelitian dengan hasil akhir kemampuan motorik halus anak berada pada kriteria Berkembang Sesuai Harapan (BSH), sedangkan hasil akhir dari kemampuan guru dalam merencanakan dan melaksanakan pembelajaran berada pada kriteria sangat baik. Kesimpulannya, kegiatan bermain konstruksi magic sand berkontribusi dalam mengembangkan kemampuan motorik halus anak usia dini.
\end{abstract}

Kata-kata Kunci: anak usia dini, kemampuan motorik halus, magic sand

\section{APPLICATION OF MAGIC SAND CONSTRUCTION PLAY IN DEVELOPING EARLY CHILDHOOD FINE MOTOR ABILITY}

\begin{abstract}
This research is motivated by the problems of undeveloped fine motor abilities in early childhood, especially fine motor skills and hands eye coordination. This study aims to improve fine motor skills in early childhood through playing the magic sand construction. This research was carried out collaboratively with class teachers by means of Classroom Action Research (CAR) method. This research was conducted in three cycles using the Kemmis and McTaggart models. The participants were 16 children, consisting of eight boys and eight girls with one partner teacher. Observation and documentation techniques were used in data collection and then analyzed using quantitative descriptive. The instrument used was in the form of structured observation with the achievement of indicators of each activity. The results showed that there was increase in fine motor skills through playing magic sand construction activities. The increase was also seen in each research cycle with the final result of fine motor skills of the participants were in
\end{abstract}


Penerapan Bermain Konstruksi...

the criteria of Developing in Accordance with Expectations (BSH), while the final result of the teacher's ability to plan and implement learning met the very good criteria. Thus, it can be concluded that the activities of playing magic sand construction contribute to developing fine motor skills of early childhood.

Keywords: early childhood, fine motor skills, magic sand

\section{PENDAHULUAN}

Setiap manusia sangatlah membutuhkan pendidikan dalam kehidupannya. Pendidikan adalah upaya yang dilakukan manusia agar dapat mengembangkan potensi dalam dirinya melalui proses pembelajaran (Sari, 2012). Sejak dini, dalam proses perkembangan pendidikan sangatlah dibutuhkan oleh manusia agar dapat berubah menjadi dewasa. Pada tahun-tahun awal anak merupakan fase perkembangan terpenting dalam menentukan kualitasnya di masa depan (Hafina, Nur \& Rusmana, 2019). Pada masa usia dini ini anak sedang berada pada masa keemasan (golden age), sekaligus masa yang menentukan perkembangan anak selanjutnya (Warniti, 2014). Masa keemasan adalah masa anak mulai sensitif atau peka terhadap berbagai rangsangan (Wahyuni, dkk 2014) dan proses perkembangan anak berjalan dengan pesat.

Pendidikan anak usia dini merupakan pemberian stimulasi, bimbingan, pengasuhan dan pemberian kegiatan pembelajaran agar aspek perkembangan anak dapat tercapai secara optimal (Sujiono, 2013). Pendidikan pada tahap ini memiliki tujuan untuk mempersiapkan anak dalam kesiapan belajar pada tahap selanjutnya dengan cara mengembangkan seluruh potensi yang ada saat ini. Dengan begitu, anak diharapkan dapat tumbuh sesuai dengan tahapan perkembangannya. Pendidikan pada anak usia dini sangat penting untuk diketahui orang dewasa baik guru maupun orang tua dalam rangka mendidik anak karena setiap aspek perkembangan anak merupakan tanggung jawab guru dan orang tua (Habsy, 2017; Hidayat \& Nur, 2018; Nur, dkk. 2019).

Lingkup perkembangan sesuai tingkat usia anak meliputi aspek nilai agama dan moral, fisikmotorik, kognitif, bahasa, sosial-emosional, dan seni (Kemendikbud, 2014; Nur, Hafina \& Rusmana, 2020). Dari penjelasan tersebut ada beberapa bidang kemampuan yang harus dikembangkan sesuai dengan tingkat usia anak diantaranya kemampuan motorik halus anak. Martinasari, dkk. (2016) menjelaskan bahwa kemampuan motorik ini menggunakan otot halus tangan maupun kaki dalam menciptakan gerakan yang diperlukan anak selama beraktivitas seperti kegiatan meremas, menulis, menyusun balok dan lain sebagainya. Motorik halus dapat didefinisikan sebagai suatu gerakan bagian tubuh tertentu yang melibatkan otot halus atau otok kecil tubuh dan tidak memerlukan tenaga yang besar hanya diperlukan koordinasi yang baik (Meilani, dkk., 2015; Skrzek, dkk., Nur, dkk., 2019).

Pada usia lima sampai enam tahun anak diharapkan dapat meningkatkan keterampilannya terutama motorik halus, melalui berbagai kegiatan sehingga tercapai tingkat pencapaian perkembangannya. Pencapaian perkembangan ini meliputi penguasaan gerakan yang melibatkan otototot kecil dan bagian-bagian tertentu. Perkembangan motorik halus ini harus distimulasi dengan baik sehingga kemampuan anak dapat berkembang yang terlihat dari koordinasi tangan dan mata berkembang secara seimbang (Putri, dkk., 2016).

Berdasarkan hasil studi pendahuluan yang dilakukan peneliti pada pada Bulan April 2018 menunjukkan bahwa secara keseluruhan kemampuan motorik halus anak hanya memperoleh persentase $24,96 \%$ dan berada pada interval $0 \%$ sampai $25 \%$. Persentase tersebut termasuk dalam kriteria belum berkembang. Hal ini teridentifikasi pada saat pembelajaran melalui kegiatan bermain membentuk menggunakan playdough, anak masih mengalami kesulitan. Anak belum mampu dan masih kaku ketika diminta untuk membuat bentuk sesuai keinginan mereka. Selain itu, pada kegiatan menggunting terlihat masih kaku, sehingga menyebabkan anak tidak dapat menggunting sesuai dengan pola yang telah ditentukan. Dari hasil diskusi dengan guru diperoleh informasi bahwa hal ini disebabkan oleh kurangnya kesempatan anak untuk bermain membentuk dan pembelajaran yang mengembangkan kemampuan motorik halus hanya memanfaatkan alat tulis berupa kertas, pensil dan krayon. Selain itu, kurang tersedianya media juga membuat guru jarang memberikan kesempatan untuk bermain. Berdasarkan permasalahan yang ada, diperlukan sebuah tindakan agar anak mampu mengembangkan kemampuan motorik halusnya secara optimal yang sesuai dengan capaian perkembangan anak tersebut melalui kegiatan bermain. Meilani, dkk. 
(2015) mengungkapkan bahwa aktivitas bermain pembangunan memiliki hubungan yang kuat dengan kemampuan motorik halus anak usia 5-6 tahun yang dilakukan dengan menggunakan media bermain pembangunan yang bersifat terstruktur seperti puzzle, balok-balok tiga dimensi, stik es dan aqua gelas. Kemudian dari hasil penelitian yang dilakukan oleh Putri, dkk. (2016) menyimpulkan bahwa terdapat peningkatan kemampuan motorik halus anak dengan menerapkan permainan konstruktif berbasis lego. Adapun hasil penelitian yang dilakukan oleh Muflihah (2014) menyimpulkan bahwa melalui media lego konstruksi yang diterapkan pada anak kelompok B mempunyai peranan yang berarti dalam mengembangkan kemampuan motorik halus anak.

Penelitian sebelumnya lebih berorientasi pada pengaruh dan korelasi permainan konstruksi terhadap perkembangan motorik halus anak, serta media yang digunakan berupa puzzle, lego, dan balok (Suarti, 2014). Sedangkan dalam penelitian ini yang akan diangkat adalah mengenai peningkatan motorik halus melalui kegiatan bermain konstruksi menggunakan media magic sand. Magic sand atau pasir ajaib ini merupakan mainan yang mirip dengan pasir namun memiliki tekstur yang lebih halus. Penggunaan magic sand telah digunakan dalam beberapa penelitian diantaranya Wahyuni, dkk. (2017) yang meneliti pengaruh bermain media pasir terhadap kreativitas pada anak usia dini yang menunjukkan hasil positif pada peningkatan kreativitas anak. Lebih lanjut Rohadatul'Aisy (2019) menyatakan bahwa media magic sands memberikan dampak yang baik terhadap kemampuan menulis permulaan pada tuna rungu kelas dasar 1 . Oleh karena itu, peneliti tertarik untuk memberikan tindakan menggunakan kegiatan bermain konstruksi magic sand pada penelitian ini untuk meningkatkan kemampuan motorik halus anak usia dini.

\section{METODE PENELITIAN}

Pada penelitian merupakan penelitian tindakan kelas sebagai salah satu upaya dalam meningkatkan proses dan hasil belajar siswa dan bermanfaat bagi guru agar dapat meningkatkan kreativitas guru dalam melakukan proses kegiatan pembelajaran dan meningkatkan kompetensi dan profesionalitas guru dalam melakukan pembelajaran (Kunandar, 2011).

Implementasi tindakan yang diterapkan adalah peningkatan kemampuan motorik halus anak usia dini melalui kegiatan bermain konstruksi magic sand. Penelitian tindakan kelas ini bersifat partisipatif dan kolaboratif antara guru, kepala sekolah, peneliti, dan anak. Dikatakan kolaboratif, karena dalam pelaksanaan penelitian ini setiap masing-masing individu yang terkait memiliki peran masing-masing dalam penelitian, tetapi pada dasarnya tetap memiliki tujuan yang sama yaitu meningkatkan kualitas pembelajaran dalam kelas.

Model penelitian tindakan kelas ini terdiri dari beberapa siklus dimana setiap siklus terdiri dari empat tahapan, yaitu tahap perencanaan, tahap tindakan, tahap observasi dan tahap refleksi. Tahapan perencanaan berisi penentuan langkahlangkah pengembangan yang dilakukan diantaranya penyusunan Rencana Pelaksanaan Pembelajaran Harian (RPPH), persiapan media pembelajaran dan penyiapan lembar observasi. Pada tahap tindakan peneliti melakukan kegiatan sesuai dengan perencanaan yang dibantu oleh guru kelas, karena penelitian tindakan kelas ini mengacu kepada penelitian kolaboratif seperti yang terlihat pada gambar 1 .

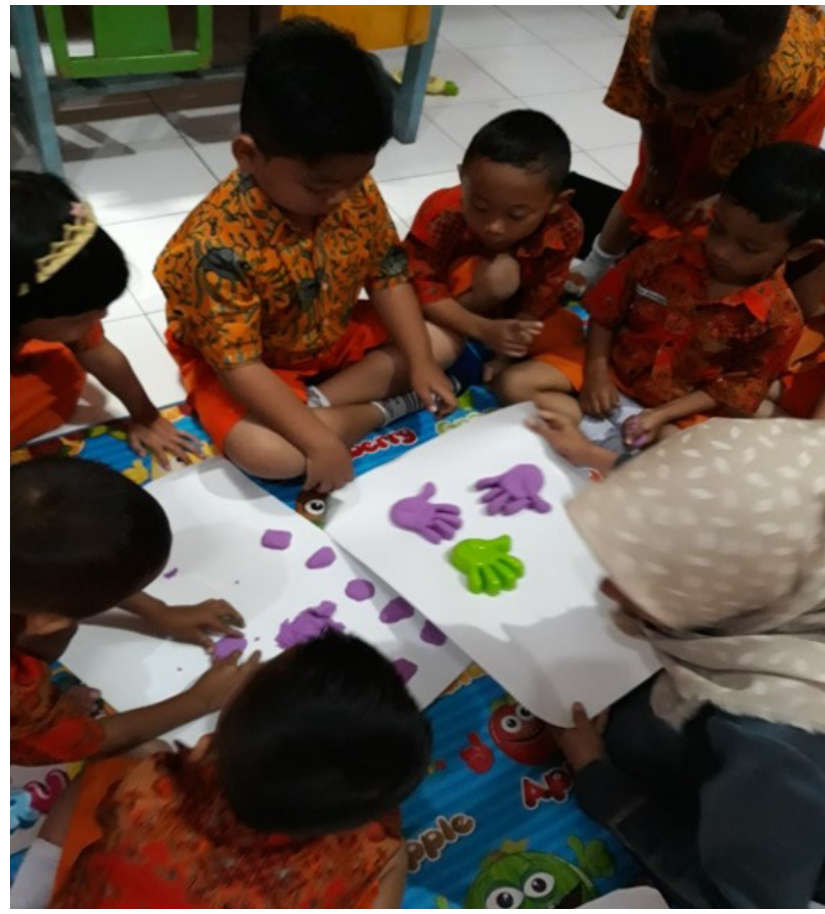

Gambar 1. Kegiatan Bermain Konstruksi Menggunakan Media Magic Sand

Selanjutnya, tahap observasi dilakukan untuk melihat dan mendokumentasi implikasi tindakan yang diberikan kepada subjek yang diteliti. Observasi dilakukan satu kali setiap siklus penelitian. Pada tahap refleksi dilakukan kegiatan diskusi peneliti dan guru untuk mengetahui hasil pelaksanaan pembelajaran sehingga dapat dicari solusi terhadap masalahmasalah yang muncul untuk perbaikan, jika diperlukan 
siklus berikutnya.

Subjek dalam penelitian ini adalah anak di kelompok B TK Perwari 1 Kota Tasikmalaya yang berjumlah 16 anak terdiri dari 8 laki-laki dan 8 perempuan. Pada Penelitian Tindakan Kelas ini peneliti dibantu oleh Guru kelas B1 sebagai pengamat dalam pelaksanaan penelitian ini.

Instrumen penelitian yang digunakan meliputi instrumen kemampuan motorik halus anak melalui kegiatan bermain konstruksi magic sand, instrumen kemampuan guru dalam perencanaan pembelajaran melalui kegiatan bermain konstruksi magic sand, dan instrumen kemampuan guru dalam proses pelaksanaan pembelajaran melalui kegiatan bermain konstruksi magic sand. Adapun kisi-kisi setiap instrument terlihat pada tabel 1, 2, dan 3 .

Tabel 1.

Kisi-Kisi Instrumen Kemampuan Motorik Halus Anak melalui Kegiatan Bermain Konstruksi Magic Sand

\begin{tabular}{|c|c|c|c|}
\hline Variabel & Sub Variabel & Indikator & Deskriptor \\
\hline \multirow{12}{*}{$\begin{array}{l}\text { Kemampuan } \\
\text { Motorik Halus }\end{array}$} & \multirow{12}{*}{$\begin{array}{l}\text { Keterampilan } \\
\text { otot-otot } \\
\text { kecil dan } \\
\text { keterampilan } \\
\text { menggunakan } \\
\text { alat }\end{array}$} & \multirow{4}{*}{ Meremas } & $\begin{array}{l}\text { Anak dapat meremas dengan menggunakan } \\
\text { seluruh jari tangan }\end{array}$ \\
\hline & & & Anak dapat meremas dengan jari jemari yang lentur \\
\hline & & & $\begin{array}{l}\text { Anak dapat meremas dengan kuat menggunakan } \\
\text { jari dan telapak tangan }\end{array}$ \\
\hline & & & $\begin{array}{l}\text { Anak dapat meremas campuran magic sand dan } \\
\text { pewarna dengan merata }\end{array}$ \\
\hline & & \multirow{4}{*}{ Membentuk } & $\begin{array}{l}\text { Anak dapat membentuk menggunakan kedua } \\
\text { tangan }\end{array}$ \\
\hline & & & $\begin{array}{l}\text { Anak dapat membuat bentuk geometri (segitiga, } \\
\text { lingkaran, dan persegi) yang mirip aslinya }\end{array}$ \\
\hline & & & Anak dapat membentuk tanpa bantuan orang lain \\
\hline & & & Anak dapat membentuk dengan rapi tanpa pecah \\
\hline & & \multirow{4}{*}{ Mencetak } & $\begin{array}{l}\text { Anak dapat menggunakan jari-jarinya untuk } \\
\text { menekan ketika mecetak }\end{array}$ \\
\hline & & & Anak dapat mencetak tanpa bantuan orang lain \\
\hline & & & Anak mengisi alat cetak hingga penuh dan padat \\
\hline & & & Anak dapat mencetak dengan rapi tanpa pecah \\
\hline
\end{tabular}

Tabel 2.

Kisi-kisi Instrumen Kemampuan Guru dalam Perencanaan Pembelajaran melalui Kegiatan Bermain Konstruksi Magic Sand

\begin{tabular}{|c|c|}
\hline Aspek & Indikator \\
\hline \multirow{4}{*}{$\begin{array}{l}\text { Merencanakan kegiatan } \\
\text { bidang pengembangan }\end{array}$} & $\begin{array}{l}\text { Pengembangan rancangan kegiatan bermain konstruksi Magic Sand sesuai } \\
\text { dengan aspek perkembangan }\end{array}$ \\
\hline & $\begin{array}{l}\text { Pengembangan kegiatan dengan kegiatan bermain konstruksi magic sand } \\
\text { sesuai dengan Tema/Sub tema tercermin pada penempatan indikator }\end{array}$ \\
\hline & $\begin{array}{l}\text { Pemilihan model pembelajaran pada kegiatan bermain konstruksi magic sand } \\
\text { sesuai dengan sifat materi kegiatan pada aspek perkembangan }\end{array}$ \\
\hline & $\begin{array}{l}\text { Kelengkapan pemilihan: metode, alat peraga dan sumber belajar sesuai dengan } \\
\text { aspek perkembangan }\end{array}$ \\
\hline \multirow[t]{4}{*}{$\begin{array}{l}\text { Merencanakan } \\
\text { pengelolaan kegiatan }\end{array}$} & $\begin{array}{l}\text { Perumusan langkah-langkah kegiatan bermain konstruksi magic sand sesuai } \\
\text { dengan tahap pencapaian perkembangan anak }\end{array}$ \\
\hline & $\begin{array}{l}\text { Pemanfaatan media dalam kegiatan bermain konstruksi magic sand sesuai } \\
\text { dengan aspek perkembangan }\end{array}$ \\
\hline & Penentuan metode yang dipilih sesuai dengan kegiatan pembelajaran \\
\hline & Menjabarkan alokasi waktu pada setiap langkah-langkah kegiatan \\
\hline
\end{tabular}




\begin{tabular}{|c|c|}
\hline \multirow{4}{*}{$\begin{array}{l}\text { Merencanakan penilaian } \\
\text { hasil dan proses, serta } \\
\text { kelengkapan dokumen }\end{array}$} & Menentukan dan merencanakan format penilaian kegiatan \\
\hline & $\begin{array}{l}\text { Menentukan dan merencanakan format penilaian penggunaan dan hasil media } \\
\text { pembelajaran }\end{array}$ \\
\hline & Menentukan kriteria keberhasilan pencapaian perkembangan \\
\hline & Kelengkapan dari lampiran-lampiran yang harus disiapkan \\
\hline
\end{tabular}

Tabel 3.

Kisi-kisi Instrumen Kemampuan Guru dalam Proses Pelaksanaan Pembelajaran melalui Kegiatan Bermain Konstruksi Magic Sand

\begin{tabular}{|c|c|c|}
\hline Variabel & Aspek & Indikator \\
\hline \multirow{13}{*}{$\begin{array}{l}\text { Bermain } \\
\text { Konstruksi } \\
\text { Magic Sand }\end{array}$} & \multirow{5}{*}{ Persiapan } & $\begin{array}{l}\text { Guru menyusun RPPH kegiatan bermain konstruksi magic sand yang } \\
\text { disesuaikan dengan tema/subtema }\end{array}$ \\
\hline & & $\begin{array}{l}\text { Guru menyiapkan media pembelajaran yang akan digunakan yaitu magic } \\
\text { sand }\end{array}$ \\
\hline & & $\begin{array}{l}\text { Guru menyiapkan alat dan bahan penunjang lainnya yang digunakan dalam } \\
\text { kegiatan bermain konstruksi }\end{array}$ \\
\hline & & $\begin{array}{l}\text { Guru menjabarkan langkah-langkah dalam kegiatan bermain konstruksi } \\
\text { magic sand }\end{array}$ \\
\hline & & $\begin{array}{l}\text { Guru mengkondisikan anak agar terfokus dalam kegiatan bermain konstruksi } \\
\text { magic sand }\end{array}$ \\
\hline & \multirow{6}{*}{ Pelaksanaan } & Guru memperkenalkan media magic sand \\
\hline & & Guru memberikan penjelasan tentang cara bermain konstruksi magic sand \\
\hline & & Guru memberikan contoh dalam kegiataan bermain konstruksi magic sand \\
\hline & & $\begin{array}{l}\text { Guru memberikan kesempatan kepada anak untuk melaksanakan kegiatan } \\
\text { bermain konstruksi magic sand }\end{array}$ \\
\hline & & Guru dapat mengendalikan situasi tidak kondusif saat kegiatan berlangsung \\
\hline & & $\begin{array}{l}\text { Guru melakukan diskusi/Tanya jawab bersama dengan anak mengenai } \\
\text { kegiatan yang telah dilakukan }\end{array}$ \\
\hline & \multirow{2}{*}{ Penilaian } & $\begin{array}{l}\text { Guru menilai kemampuan anak dalam aspek keterampilan otot-otot halus } \\
\text { yaitu meremas, membentuk dan mencetak }\end{array}$ \\
\hline & & Guru menilai kemampuan anak dalam aspek keterampilan penggunaan alat \\
\hline
\end{tabular}

Observasi dan dokumentasi digunakan dalam pengumpulan data penelitian yang selanjutnya dianalisis menggunakan deskriptif kuantitatif dengan teknik persentase. Kriteria penilaian yakni nilai persentase $0 \%-25 \%$ berarti kurang, nilai persentase $26 \%-50 \%$ berarti cukup, nilai persentase $51 \%-75 \%$ berarti baik, dan nilai persentase $76 \%-100 \%$ berarti sangat baik. Pada penilaian kemampuan motorik halus, peneliti mengambil 4 kriteria persentase yang di adaptasi dari pendapat Yoni (2010) yaitu persentase $0 \%-25 \%$ artinya BB (Belum Berkembang), persentase 26\%-50\% artinya MB (Mulai Berkembang), persentase $51 \%-75 \%$ artinya BSH (Berkembang Sesuai Harapan), dan persentase $76 \%-100 \%$ artinya BSB (Berkembang Sangat Baik).

Adapun indikator keberhasilan dalam penelitian ini adalah sebagai berikut:

a. Guru mengalami peningkatan kemampuan dalam proses perencanaan pembelajaran dan pelaksanaan pembelajaran.

b. Peningkatan kemampuan guru dalam pengelolaan proses pembelajaran melalui kegiatan bermain konstruksi magic sand.

c. Anak mengalami peningkatan dalam kemampuan motorik halus melalui kegiatan bermain konstruksi magic sand.

\section{HASIL DAN PEMBAHASAN}

Hasil

Penelitian ini bertujuan untuk untuk meningkatkan kemampuan motorik halus pada anak usia dini melalui kegiatan bermain konstruksi magic sand. Pada siklus
I terlihat bahwa kemampuan guru dalam membuat RPPH berada pada kriteria cukup dengan persentase $47,91 \%$ dan selanjutnya diperbaiki pada perencanaan selanjutnya. Pada siklus II, kekurangan sudah 
diperbaiki namun dalam kesesuaian tema dengan kegiatan masih belum diperbaiki secara optimal dikarenakan beberapa kendala sehingga kemampuan guru dalam membuat RPPH pada siklus II memperoleh persentase sebesar $62,5 \%$ yang masuk dalam kriteria baik. Kekurangan diperbaiki pada siklus III sehingga capaian persentase meningkat menjadi $79,16 \%$ dengan kriteria sangat baik. Rekapitulasi Persentase Kemampuan Guru dalam Perencanaan disetiap siklus dapat dilihat pada gambar 2 .

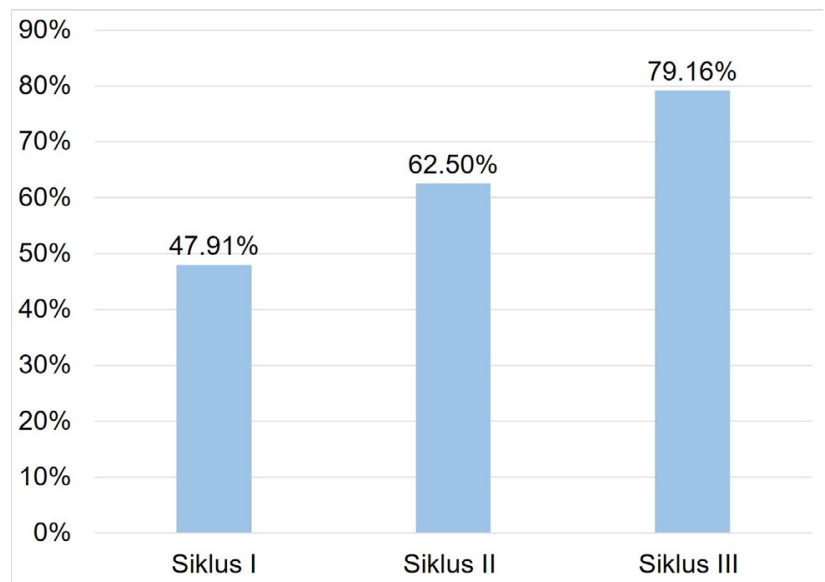

Gambar 2. Rekapitulasi Persentase Kemampuan Guru dalam Perencanaan Pembelajaran Siklus I, II, dan III

Pada proses pelaksanaan kegiatan bermain konstruksi magic sand secara umum dari hasil observasi kemampuan guru mengalami peningkatan pada setiap siklus. Dari data hasil observasi pada siklus I diperoleh beberapa kelemahan di antaranya guru masih kurang mampu dalam mengkondisikan anak dan mengendalikan situasi yang tidak kondusif, sehingga anak kurang memperhatikan dan kurang tertarik mengikuti kegiatan berlangsung, selain itu juga guru dalam menjelaskan langkah-langkah kegiatan bermain konstruksi magic sand masih belum jelas dan kurang menarik perhatian anak sehingga ketika saat melakukan sesi diskusi/Tanya jawab anak masih banyak yang belum mengerti. Pada siklus I, kemampuan guru mencapai skor 25 dengan persentase $48,07 \%$ dan masuk dalam kriteria cukup. Kekurangannya sudah diperbaiki sehingga pada siklus II kegiatan penjelaskan langkah-langkah sudah jelas dan ketika melakukan sesi diskusi/tanya jawab pun anak sudah lebih mengerti. Dengan adanya perbaikan tersebut, hasil observasi kemampuan guru dalam pelaksanaan kegiatan bermain konstruksi magic sand pada siklus II dapat meningkat. Namun pada siklus II pun masih ada kelemahan yaitu guru masih kurang menguasai kelas ketika situasi tidak kondusif. Pada siklus II kemampuan guru mencapai skor 37 dengan persentase $71,1 \%$ dan berada dalam kriteria baik. Pada siklus III merupakan tahap penilaian dari kegiatan bermain konstruksi magic sand, kekurangan pada siklus sebelumnya sudah diperbaiki, sehingga kemampuan guru dalam kegiatan bermain konstruksi magic sand mencapai skor 45 dengan persentase $86,53 \%$ dan termasuk pada kriteria sangat baik.

Secara umum hasil observasi kemampuan guru dalam pelaksanaan kegiatan bermain konstruksi magic sand mendapatkan peningkatan. Hal tersebut karena adanya persiapan dan perbaikan dengan melihat pada hasil refleksi dari masing-masing siklus. Rekapitulasi persentase kemampuan guru dalam pelaksanaan pembelajaran pada setiap siklus dapat dilihat pada gambar 3 .

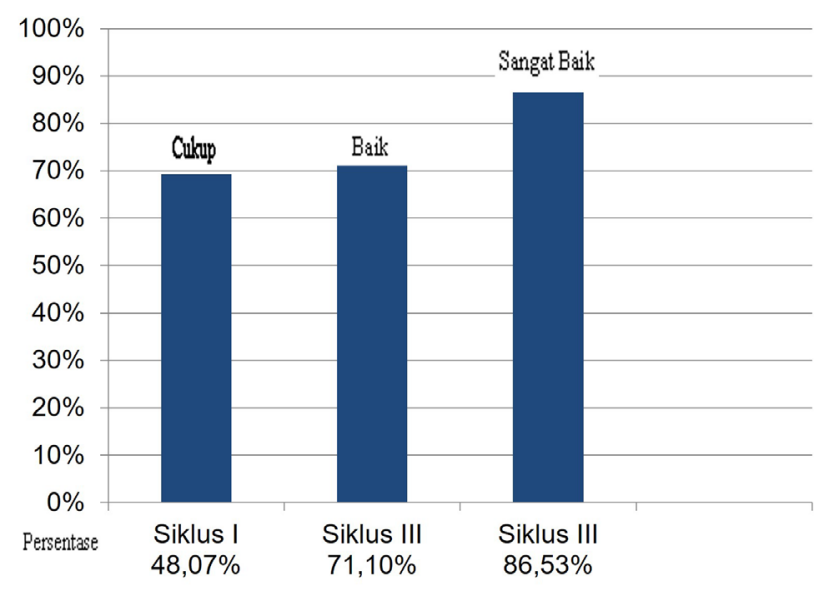

Gambar 3. Rekapitulasi Persentase Kemampuan Guru dalam Pelaksanaan Pembelajaran pada Setiap Siklus

Pada gambar 4 terlihat kemampuan motorik halus anak pada indikator meremas, membentuk dan mencetak magic sand, pada siklus I pada kriteria Belum Berkembang (BB) sebanyak delapan anak dengan persentase $57,1 \%$, dan enam anak dengan persentase $42,9 \%$ berada pada kriteria Mulai Berkembang (MB). Sedangkan pada siklus II, kriteria Belum Berkembang (BB) terdapat empat anak dengan persentase $26,7 \%$, pada kriteria Mulai Berkembang (MB) terdapat tujuh anak dengan persentase $46,6 \%$, dan empat anak dengan persentase $26,7 \%$ berada pada kriteria Berkembang Sesuai Harapan (BSH). Pada siklus III terdapat lima anak dengan persentase 33,3\% pada kriteria Mulai Berkembang (MB), enam anak dengan persentase $40 \%$ pada kriteria Berkembang Sesuai Harapan (BSH) dan pada kriteria Berkembang Sangat Baik (BSB) terdapat empat anak dengan persentase $26,7 \%$. Secara keseluruhan terdapat peningkatan dari siklus pertama, kedua, dan ketiga dengan hasil bahwa tidak terdapat kategori Belum Berkembang (BB) pada siklus terakhir. 


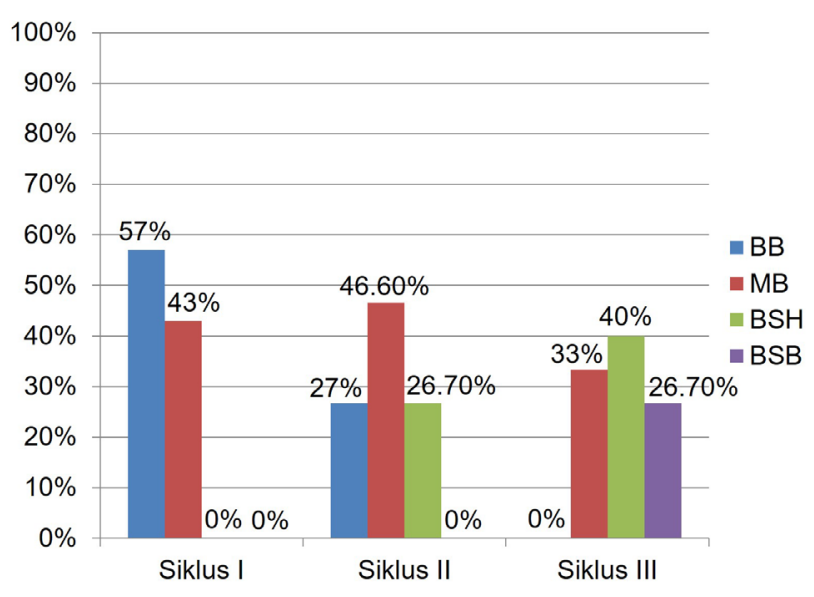

Gambar 4. Rekapitulasi Peningkatan Kemampuan Motorik Halus Anak

\section{Pembahasan}

Keterampilan motorik halus adalah kemampuan yang melibatkan otot halus dan koordinasi mata tangan dan berhubungan dengan keterampilan fisik (Skrzek, 2015). Perkembangan motorik halus anak sangatlah penting karena berpengaruh terhadap strategi pembelajaran lainnya, termasuk dalam keterampilan sehingga penyesuaian sosial anak semakin baik (Nurfarida, 2016). Hal tersebut sejalan dengan pernyataan dari Marr, dkk. (2003) yang menyatakan bahwa keterampilan motorik halus merupakan aspek yang penting bagi pertumbuhan dan perkembangan anak guna menunjang anak-anak dalam kegiatan sehari-hari, bermain dan bersosialisasi.

Temuan di lapangan terlihat pada saat bermain konstruksi magic sand yaitu membentuk magic sand menjadi bentuk geometri (segitiga, lingkaran, dan persegi) dan bentuk tangan anak merasa sangat antusias melakukan aktivitas tersebut. Setelah guru mencontohkan langkah-langkah pembuatannya, anak langsung memilih bentuk apa yang mereka inginkan. Hasil temuan ini memperkuat temuan sebelumnya bahwa penggunaan magic sand memiiki kontrbusi positif dalam meningkatkan motorik halus anak. Selain itu, kreativitas anak turut meningkat pada saat proses pembelajaran karena pada dasarnya anak menyukai aktivitas bermain. Temuan ini, diperkuat penelitian sebelumnya bahwa bermain menggunakan media pasir dapat meningkatkan kreativitas pada anak usia dini (Wahyuni, 2017). Keterampilan motorik halus anak yang terlihat ketika aktivitas meremas, membentuk dan mencetak menunjukkan peningkatan kemampuan anak. Lebih lanjut, penerapan media magic sand dapat meningkatkan kemampuan menulis anak (Rohadatul'Aisy, 2019).

Sejalan dengan temuan penelitian, Hasanah (2016) dalam hasil penelitiannya menjelaskan bahwa kemampuan fisik motorik dapat dikengembangan melalui permainan tradisional bagi anak usia dini. Lebih lanjut, Febrianta (2016) menambahkan bahwa diperlukan pemahaman dari orang tua, guru, dan berbagai pihak pada hakikatnya bermain pada masa anak merupakan cara anak dalam berkembang dan mengembangkan potensinya sehingga diperlukan berbagi jenis-jenis permainan yang dapat menstimulus perkembangan tersebut diantaranya bermain dengan magic sand. Penggunaan media yang inovatif dan tepat yang diterapkan dalam proses pembelajaran akan membantu peningkatan hasil belajar siswa (Malik,dkk, 2013).

\section{PENUTUP}

\section{Kesimpulan}

Penelitian ini dapat menyimpulkan bahwa: (1) kemampuan guru dalam merancang perencanaan pembelajaran melalui kegiatan bermain konstruksi magic sand untuk meningkatkan kemampuan motorik halus anak mengalami peningkatan pada setiap siklus, dengan memperhatikan petunjuk penelitian tindakan kelas dan hasil refleksi juga perbaikan pada setiap siklus. (2) Kemampuan guru dalam melaksanakan pembelajaran melalui kegiatan bermain konstruksi magic sand untuk meningkatkan kemampuan motorik halus anak meningkat sesuai dengan kriteria keberhasilan, dimana pelaksanaan tersebut dilengkapi dengan lembar instrumen aktivitas guru dalam melaksanakan pembelajaran melalui kegiatan bermain konstruksi magic sand. Kinerja guru dalam melaksanakan pembelajaran melalui kegiatan bermain konstruksi magic sand mengalami peningkatan pada setiap siklusnya. Peningkatan kemampuan guru dalam menerapkan kegiatan bermain konstruksi magic sand pada pembelajaran, dikarenakan telah memperbaiki hasil evaluasi pada setiap siklusnya. Jadi, kemampuan guru dalam setiap siklusnya mengalami peningkatan. (3) Peningkatan pada aspek perencanaan dan pelaksanaan pembelajaran berdampak pada peningkatan kemampuan motorik halus. Kemampuan motorik halus anak mengalami peningkatan setelah menggunakan kegiatan pembelajaran melalui kegiatan bermain konstruksi magic sand pada proses pembelajaran selama tiga siklus penelitian, peningkatan yang terjadi sudah mencapai indikator keberhasilan yang telah ditentukan. 


\section{Implikasi}

Implikasi dari penelitian ini dapat memberikan informasi mengenai kegiatan pembelajaran melalui kegiatan bermain konstruksi magic sand dalam pembelajaran dapat meningkatkan kemampuan motorik halus anak. Disamping itu, dapat memotivasi guru untuk menciptakan inovasi dalam kegiatan pembelajaran yang lebih efektif serta memberikan gambaran kepada guru dalam merancang pembelajaran melalui kegiatan bermain konstruksi magic sand.

\section{Rekomendasi}

Peneliti merekomendasikan bahwa proses pembelajaran yang dilakukan guru dapat dijadikan landasan bahwa kegiatan pembelajaran pada anak usia dini tidak hanya belajar sebatas paper pencil. Guru dapat memilih kegiatan yang tepat, cocok, bervariasi, sesuai dengan kebutuhan dan dapat menarik minat anak. Bagi sekolah, diharapkan dapat memfasilitasi dan menerapkan beberapa kegiatan yang sesuai dengan minat dan kebutuhan anak. Sekolah tidak hanya menerapkan kegiatan paper pencil saja. Bagi peneliti selanjutnya, agar dapat berinovasi dengan menerapkan jenis metode pendekatan bermain yang lain dan membandingkannya untuk mengetahui kefektifitasannya.

\section{DAFTAR PUSTAKA}

Febrianta, Y. (2016). Alternatif Mengembangkan Kemampuan Motorik Kasar Anak Usia Dini Dengan Aktivitas Akuatik (Berenang). Al-Athfal: Jurnal Pendidikan Anak, 2 (2), 85-95.

Habsy, B. A. (2017). Model konseling kelompok cognitive behavior untuk meningkatkan self esteem siswa SMK. Perspektif IImu Pendidikan, 31(1), 21-35. DOI: 10.21009/PIP.311.4

Hasanah, U. (2016). Pengembangan kemampuan fisik motorik melalui permainan tradisional bagi anak usia dini. Jurnal Pendidikan Anak, 5(1), 717-733. DOI: $10.21831 /$ jpa.v5i1.12368

Hidayat, S. \& Nur, L. (2018). Nilai Karakter, Berpikir Kritis dan Psikomotorik Anak Usia Dini. Jurnal IImiah Visi. 13(1), 29-35. DOI: https://doi. org/10.21009/JIV.1301.4

Hafina, A., Nur, L., \& Rusmana, N. (2019). Basic Attitude Ability of Early Childhood in Aquatic Learning. Proceeding, $2^{\text {nd }}$ International Conference on Educational Science (ICES 2018). DOI : 10.2991/ices-18.2019.8

Kemendikbud. (2014). Peraturan Menteri Pendidikan dan Kebudayaan Republik Indonesia Nomor 137 Tahun 2014 tentang Standar Nasional Pendidikan Anak Usia Dini. Jakarta: Kementrian Pendidikan dan Kebudayaan.

Kunandar. (2011). Peneitian Tindakan Kelas sebagai Pengembangan Profesi Guru. Jakarta: PT Rajagrafindo Persada.

Malik, A. A.; Priyono, B.; Qoriah, A. (2013). Ular Tangga Olahraga. Media Permainan Edukatif untuk Olahraga dengan Menggunakan Sistem Sirkuit Training bagi Siswa Kelas X SMA Negeri Ajibarang Tahun 2013. ACTIVE: Journal of Physical Education, Sport, Health and Recreations. 2 (10) 630-636. DOI: 10.15294/ active.v2i10.2018

Marr, D., Cermak, S., Cohn, E. S., \& Henderson, A. (2003). Fine Motor Activities in Head Start and Kindergarten Classrooms. The American Journal of Occupational Therapy, 57, 550-557. DOI: 10.5014/ajot.57.5.550

Martinasari, K. S., Putra, I. K. A., \& Darsana, I. W. (2016). Penerapan metode pemberian tugas melalui kegiatan usap abur untuk meningkatkan keterampilan motorik halus pada anak. Jurnal Pendidikan Anak Usia Dini Undiksha, 4(2). DOI: 10.23887/paud.v4i2.7844

Meilani, S., Sofia, A., \& Riswandi, R. (2015). Hubungan Antara Aktivitas Bermain Pembangunan Dengan Kemampuan Motorik Halus Anak 5-6 Tahun. Jurnal Pendidikan Anak. 1(3). Diakses melalui http://jurnal.fkip.unila.ac.id/index.php/ PAUD/article/view/9621

Muflihah, A. (2014). Upaya Mengembangkan Kemampuan Motorik Halus dengan Media Lego Konstruksi pada Anak Kelompok B di TK BA Sentono Ngawonggo Ceper Klaten Tahun Ajaran 2013/2014. Skripsi tidak diterbitkan. Surakarta: Universitas Muhamadiyah Surakarta Nur, L., Hafina, A., Rusmana, N., Suryana, D., \& Malik, A. A. (2019). Basic Motor Ability: Aquatic Learning for Early Childhood. ACTIVE: Journal of Physical Education, Sport, Health and Recreation, 8(2), 51-54. DOI: 10.15294/active.v8i2.28406

Nur, L., Hafina, A., Rusmana, N., \& Bakhri, R. S. (2019). Kemampuan Motorik Dasar Anak Usia Dini dalam Pembelajaran Akuatik. Jurnal IImiah VISI PGTK PAUD dan Dikmas, 14 (2), 133-140. DOI: 10.21009/JIV.1402.6

Nur, L., Hafina, A., \& Rusmana, N. (2020). Kemampuan Kognitif Anak Usia Dini dalam Pembelajaran 
Akuatik. Scholaria: Jurnal Pendidikan dan Kebudayaan, 10(1), 42-50. DOI: 10.24246/j. js.2020.v10.i1.p42-50

Nurfarida, A. (2016). Mengembangkan Kemampuan Motorik Halus dengan Membentuk Buah melalui Media Playdough pada Kelompok A TK PGRI Kepuhrejo di Kabupaten Tulungagung Tahun Pelajaran 2015/2016. Skripsi Tidak Diterbitkan. Kediri: Universitas Nusantara Pendidikan Guru Republik Indonesia.

Putri, NPRU; Antara, PA; Tirtayani LA. (2016). Pengaruh Permainan Konstruktif terhadap Kemampuan Motorik Halus Anak Kelompok A2 Rabaitulmutaallim Tegalinggah Singaraja. Jurnal Pendidikan Anak Usia Dini Undiksha, 4 (3). DOI: 10.23887/paud.v4i3.8725

Rohadatul'Aisy, A. R. (2019). Pengaruh Media Magic Sands terhadap Kemampuan Menulis Permulaan pada Tunarungu Kelas Dasar 1. Jurnal Widia Ortodidaktika, 8 (12), 1241-1250. Diakses melalui http://journal.student.uny.ac.id/ ojs/index.php/plb/article/download/16076/15555

Sari, E.K. (2012). Peningkatan Perkembangan Motorik Halus Anak melalui Kegiatan Kolase dari Bahan Bekas di Taman Kanak-Kanak Aisyiyah Simpang IV Agam. Jurnal Pesona PAUD. 1 (1), 1-11. Diakses melalui http://ejournal.unp.ac.id/ index.php/paud/article/view/1615

Skrzek, A., Přidalová, M., Sebastjan, A., Harásková, D., Fugiel, J., Ignasiak, Z., ... \& Rozek, K. (2015). Fine motor skills of the hands in Polish and Czech female senior citizens from different backgrounds. Aging clinical and experimental research, 27 (4), 491-498. DOI: 10.1007/ s40520-014-0299-7

Suarti, N.K.A. (2014). Bermain Konstruktif Sambil Belajar Konsep Bilangan pada Anak Usia 5-6 Tahun. Jurnal Paedagogy. 1 (2), 140-150. Mataram: FIP IKIP Mataram.

Sujiono, Y.N. (2013). Konsep Dasar Pendidikan Anak Usia Dini. Jakarta: Indeks.

Wahyuni, NNR; Asri, AAS; Suniasih, NW. (2014). Penerapan Metode Demonstrasi dengan Lingkungan sebagai Sumber Belajar untuk Meningkatkan Keterampilan Motorik Halus Anak. Jurnal Pendidikan Anak Usia Dini Undiksha, 2 (1). DOI: 10.23887/paud.v2i1.3238 Wahyuni, S.; Rahelly, Y.; Syafar, S. (2017). Pengaruh Bermain Media Pasir Terhadap Kreativitas pada Anak di Kelompok B TK Negeri Pembina 2 Palembang. Tumbuh Kembang: Kajian Teori dan Pembelajaran PAUD, 4 (2), 66-74. DOI: 10.36706/jtk.v4i2.8176

Warniti. (2014). Penerapan Metode Pemberian Tugas dengan melalui Kegiatan Meronce untuk Meningkatkan Perkembangan Motorik Halus Anak Kelompok B. e-Journal PG-PAUD Universitas Pendidikan Ganesha, 2 (1). Diakses melalui https://ejournal.undiksha.ac.id/index. php/JJPAUD/article/viewFile/3628/2921

Yoni, A. (2010). Menyusun Penelitian Tindakan Kelas. Yogyakarta: Familia. 
Penerapan Bermain Konstruksi...

72 VISI : Jurnal IImiah PTK PNF - Vol. 15 No. 1, Juni 2020 